JAZYKOVEDNÝ ČASOPIS, 2017, roč. 68, č. 3

\title{
RECENZIE A SPRÁVY
}

ČERMÁK, František et al. (2009, 2016): SLOVNÍK ČESKÉ FRAZEOLOGIE A IDIOMATIKY. Sv. 1 - Přirovnání; Sv. 2 - Výrazy neslovesné; Sv. 3 - Výrazy slovesné; Sv. 4 - Výrazy větné; Sv. 5 - Onomaziologický slovník. Praha: Leda, 507 s.; 547 s.; 1247 s.; 1267 s.; 528 s. ISBN 978-80-7335-2165; ISBN 978-80-7335-2172; ISBN 978-80-7335-2189; ISBN 97880-7335-2196; ISBN 978-80-7335-440-4. ${ }^{1}$

S ohledem na množství kvalitních publikací k frazeologii a solidní teoretickou i materiálovou bázi ke slovníkovému zpracování frazémů ${ }^{2}$ je snad až s podivem, že se v evropských frazeologických i jiných pracích dodnes opakovaně - a oprávněně - konstatuje frazeografický deficit. Jednou z mála, ne-li jedinou výjimkou je zde frazeologie a frazeografie česká, zosobněná jednak profesorem Františkem Čermákem, jednak Slovnikem české frazeologie a idiomatiky (dále jen SČFI), vzniklým pod jeho vedením.

Od 60. let 20. století ${ }^{3}$ se na půdě Univerzity Karlovy (v prrípadě 2. dílu v Ústavu pro jazyk český AV) budovala jak materiálová základna, tak teoretická koncepce frazeologie, která zpětně ovlivňovala frazeografický model stojící na pozadí SČFI. A právě tato vzácná symbióza fundovaných obecnělingvistických vědomostí a teoreticky propracovaného konceptu frazému, ${ }^{4}$ exaktní lexikografické metody a zkušeností jak z frazeografické, tak i pedagogické praxe, patrně stojí za jedinečností SČFI. Jeho autoři ${ }^{5}$ se přitom nemohli oprrít o kva-

${ }^{1}$ Martin Šemelík na této recenzi pracoval v rámci projektu Univerzity Karlovy Progres č. 4, Jazyk $v$ proměnách času, mista, kultury.

${ }^{2}$ Viz např́íklad databanku publikací na stránkách organizace EUROPHRAS, http://www.europhras.org/ (1. 9. 2017), nebo bibliografii Wolfganga Miedera (Mieder 2009).

${ }^{3}$ Česká frazeologie je součástí rukopisných i tištěných sbírek již po staletí. V této souvislosti zmiňme např. Tripartius moralium (1360) Konrada z Halberstadtu, Dicteria seu proverbia Bohemica (1582), Moudrost starých Čechů (1631) Jana Amose Komenského či Lidová rčeni (1947) Jaroslava Zaorálka. Literárněvědné studie viz např. Mukařovský (1971). Podrobněji srov. Schindler (1993) a Henschel (1993, s. 23 - 35).

${ }^{4}$ Termín frazém zde užíváme s odkazem na terminologii užívanou již od 80. let Františkem Čermákem a v souladu s návrhem zavést jednotný terminologický úzus (viz např. Burger - Dobrovol'skij Kühn - Norrick, 2007, s. 3). Naše pojetí frazému vychází z jeho definice u Františka Čermáka (viz např̀. Čermák, 2007, s. 32).

${ }^{5}$ Spolu s Františkem Čermákem, resp. Jiřím Hronkem a Jaroslavem Machačem jako dalšími hlavními editory pracovali na jednotlivých svazcích SČFI i OSČFI v různých etapách (abecedně) Renata Blatná, Vlasta Červená, Kamila Filipová, Jan Holub, Miloslav Churavý, Ladislav Janský, Marie Kopřivová, Libuše Kroupová, Jiřina Luttererová, Vladimír Mejstřík, Jiřina Sedláková, Milan Šára, Vlasta Šustalová, Zdeněk Švamberk, Alena Trnková, Emil Vejvoda, Jaroslav Zima. Cizojazyčné ekvivalenty vypracovali (abecedně) Ljubov N. Běloruss-Běloševská, Tatjana V. Danilovová, Oleg Fedosov, Madeleine Gasnierová, Marie-Line Jouannaux, Jürgen Ostmeyer, Patrice Pognan, David Short, Ludmila Stěpanova. 
litní zpracování frazémů ve všeobecných jednojazyčných slovnících češtiny ani ve slovnících překladových. ${ }^{6}$

První díl SČFI vyšel v roce 1983 v nakladatelství Academia, v následujících jedenácti letech přibyly další dva svazky. Uživatelům tak bylo předloženo relativně úplné zpracování nevětných frazémů (SČFI 1 - Přirovnáni 1983, SČFI 2 - Výrazy neslovesné 1988, SČFI 3 Výrazy slovesné 1994). Význam SČFI už tehdy spočíval nejen v množství zpracovaných hesel a rozsahu heslových statí, cizojazyčných ekvivalentů, odkazů a (sémantických) rejstř́ků, ale především v teoretické bázi, stojící za jejich zpracováním. Hlavní editor těchto svazků i dílů následujících, František Čermák, opatřil všechny slovníky podrobnou studií té které oblasti frazeologie, prričemž všechny svazky mají také obsáhlou předmluvu vysvětlující zásady zpracování a užívání daného dílu. ${ }^{7}$

V roce 2009 vydalo nakladatelství Leda čtvrtý svazek věnovaný frazémům propozičním (SČFI 4 - Výrazy větné), opět doplněný teoretickým výkladem. Zároveň s tímto slovníkem bylo uživatelům nabídnuto druhé vydání tří předchozích. Dle autorů bylo do nového vydání nově zařazeno cca 600 hesel. Předností této edice je, že se autoři mohli při doplňování hesel nebo ověřování úzu či příkladů opřít o Český národni korpus. Lze tedy konstatovat, že v těchto slovnících bylo dosaženo podrobného popisu víceslovných frazémů češtiny, a to pro zhruba 37 tisíc jednotek. $^{8}$

V následující skice budeme SČFI charakterizovat a zároveň shrneme, čím je jeho přístup výjimečný. ${ }^{9}$ Zvýšenou pozornost budeme věnovat nejnovějšímu svazku (SČFI 5 Onomaziologický slovník) z roku 2016. Tato recenze, jež samozřejmě na daném prostoru nemůže veškeré aspekty zpracování obsáhnout vyčerpávajícím způsobem, je psána z perspektivy metalexikografické i uživatelské.

SČFI je slovník tištěný. Layout je zdařilý, snad kromě velikosti písma, jež by zejména pro starší uživatele a hlavně v případě doprovodných textů mohlo být na hraně čitelnosti. Na stránce najdeme dva textové sloupce a indikaci prvního a posledního lemmatu umístěnou na horním okraji. Užívání usnadňuje palcový rejstř́ík. Kvalita papíru je velmi dobrá.

SČFI lze charakterizovat jako slovník speciální, synchronní, primárně jednojazyčný a sémaziologický (SČFI 1 - 4), s formálním, abecedním řazením hesel. Slovník má dvojí přístupovou strukturu, ${ }^{10}$ která je dána prezencí sémantického rejstř́iku na konci každého svazku,

${ }^{6} \mathrm{~K}$ tomu na příkladu př́sloví ve Slovníku spisovného jazyka českého, Př́ručním slovníku jazyka českého a Česko-německém slovníku srov. Šichová - Šemelík (2016, s. 70 - 99). K německo-českému frazeologickému slovníku viz Šemelík (2010) a Šichová (2011).

${ }^{7}$ Své pojetí frazeologie představil František Čermák již na počátku 80. let (srov. Čermák, 1982), později v rámci spolupráce s Josefem Filipcem v kontextu lexikologickém (Filipec - Čermák, 1985). Výběr jeho prací, jehož jádro tvoří právě teoretické statě ze SČFI, vyšel pak v češtině s obsáhlými anglickými shrnutími na začátku tisíciletí (Čermák, 2007). Frazeografické zásady uplatněné i v SČFI jsou představeny mj. v Manuálu lexikografie (viz Čermák - Blatná, 1995).

${ }^{8}$ Slovník ve třech svazcích věnovaných jen kolokačním frazémům obsahuje téměř 17 tisíc hesel, k nimž však eviduje navíc na 10 tisíc kvazifrazémů verbálních. Frazémy propoziční lze odhadnout na dalších 10 tisíc hesel (viz Čermák, 2007, s. 621 a SČFI 1, s. 9).

${ }^{9}$ Starší recenze viz např. Petráčková (1985), Kučera (1995), nověji Jarošová (2011).

${ }^{10}$ Pod pojmem př́stupová struktura rozumíme množinu prvků, jež uživateli slovníku slouží jako opěrné body k orientaci při vyhledávání heslových statí (viz Engelberg - Lemnitzer, 2009, s. 272n.). 
umožňujícího hesla vyhledávat také podle principu onomaziologického (SČFI 1 - 4). Tato skutečnost rozšiřuje spektrum možných užití slovníku, nebot' uživatelé v něm mohou najít mj. referenční příručku ke zjištění vhodného frazeologického výrazu k dané významové oblasti. Z těchto rejstř́ků pak vznikl onomaziologický svazek SČFI $5 \mathrm{~s}$ jednou přístupovou strukturou (podrobněji viz dále).

Součástí SČFI 1 - 4 je několik doprovodných textů, např. Předmluva, Zásady zpracování a uživání slovniku, ${ }^{11}$ Seznam zkratek a značek, jakož i obsáhlá lingvistická studie k dané oblasti frazeologie.

Za zmínku stojí princip řazení hesel v SČFI 1 - 4, popsaný v jedné z úvodních kapitol. Oproti stěží uchopitelnému, ale např. v německé frazeografii zcela běžnému principu uspořádání hesel podle tzv. „hlavní komponenty“12 rezignuje SČFI na určení (mnohdy neurčitelného) sémantického jádra frazému a na z toho plynoucí nutnost odkazů. Vytyčuje jednoznačná kritéria vycházející z kategoriálních a funkčních principů, resp. kombinace „„̌́tyř hlavních slovních druhů, nesoucích ve slovníku většinu významů“ (SČFI 1, s. 7), tj. prvního substantiva, resp. adjektiva, resp. verba, resp. adverbia, s abecedou. V každém svazku je tento princip vysvětlen a ilustrován.

Dalším pozitivem je detailní výstavba heslové statě. ${ }^{13}$ Konstituují ji záhlaví s invariantní podobou frazému a jeho variantami syntagmatickými i paradigmatickými a valencí, stylová charakteristika frazému, ${ }^{14}$ gramatická charakteristika, resp. negativně vymezené kategorie, ${ }^{15}$

Většina slovníků má jednu př́ístupovou strukturu, což znamená, že se ke stati (resp. určité informaci) lze dostat jen tak, že ji uživatel nalistuje v hesláři. Dvojí (řidčeji i např. trojí atd.) prŕstupová cesta je k dispozici tehdy, pokud má slovník více rejstříků, ne jen jeden hlavní heslár.

${ }^{11} \mathrm{~V}$ této části čtenář najde podrobné a konkrétními př́iklady doplněné informace, rozdělené do následujících kapitol: Cíl a povaha slovniku, Výběr hesel a jejich uspořádání, Typy hesel, Součásti výkladové heslové stati (Podoba záhlaví, Stylová charakteristika, Gramatická charakteristika a úzus, Transformace, Kontext a valence, Význam, Exemplifikace, Dalši údaje o úzu, etymologii, struktuře, variantách, transformacich výrazu a souvislosti s výrazy jinými, Synonymie a opozitnost užši a širší, funkční ekvivalence a kontrastnost př́má a nepřimá, Cizojazyčné ekvivalenty). Jejich bližší popis včetně příkladů viz Jarošová (2011).

${ }^{12}$ První slovo, nebo některé z „nejdůležitějších slov“ frazému nesoucí význam.

${ }^{13}$ Srov. i Jarošová (2011).

${ }^{14}$ SČFI „odhližži“ od „hlediska spisovnosti jako př́lišs širokého a pro frazeologii a idiomatiku málo relevantního“" (SČFI 1, s. 18). To se projevuje v chápání pojmu kolokviálnosti jako běžně mluvené podoby jazyka. Jde zde tedy o výrazy hovorové spisovné i nespisovné, pokud nejsou lokálně omezené. Kritérium (ne)spisovnosti je uplatňováno, pokud se výrazy užívají „toliko v nespisovné podobě“ (SČFI 1, s.15), např.: je to (velký) jako bejk. V tom případě jsou frazémy řazeny pouze pod nespisovnou podobou. Uvádění dublet však není důsledné, srov. např́klad lokál plurálu noha: V invariantu frazému být na nohou by bylo vhodné uvést i formu nohách, která se v korpusu vyskytuje rovněž často. Též substandardní (obecněčeské) varianty typu bejt nebo slabej jsou ve slovníku uváděny nejednotně, srov. být slabý/bejt slabej na prsa vs. být s nervama hotovej vs. být zadlužený až po uši (blíže viz Šichová, 2013, s. 317 aj.).

${ }^{15} \mathrm{~V}$ tomto kontextu se nabízí otázka, zda negativní vymezení charakteristiky frazémů není do jisté míry problematické, nebot' empirická data lze interpretovat pouze pozitivně. Negativní závěry možné de facto nejsou, protože nedoloženost jevu nemusí nutně znamenat jeho neexistenci. Vysvětlením může být i neúplnost korpusu (srov. Perkuhn - Belica, 2006, s. 4) či vlastních excerpcí. Metodologie, která by tyto dvě možné interpretace zcela jednoznačně desambiguovala, zdá se, $\mathrm{k}$ dispozici není. Také introspekce zde může, ale nemusí pomoci. Diskuzi pozitiv a negativ vymezení pozitivního ovšem nemůžeme vést na tomto místě. 
ustálené transformace (např. nominalizace horká hlava/krev u slovesného frazému mit horkou hlavu/krev), sémantický oddíl s vymezením aktantů a jejich vzájemného vztahu, popisem významu frazému včetně naznačení jeho pragmatické složky či složky gestové, výběrová exemplifikace, ${ }^{16}$ údaje o úzu nebo etymologii, synonyma, ekvivalenty a antonyma, a u frekventovaných frazémů i jejich anglický, německý, francouzský či ruský ekvivalent. ${ }^{17}$ SČFI 4 s ohledem na to, že mezi stálé formální rysy inventarizovaného typu frazémů patř́ jejich intonace, uvádí i její charakteristiku. ${ }^{18}$

Základem jakéhokoli slovníku je mj. i vymezení objektu zájmu, v př́padě SČFI tedy frazému. František Čermák frazém ${ }^{19}$ definuje prizmatem pravidelnosti a anomálie jako „takové nemodelové a ustálené syntagma prvků, z nichž (aspoň) jeden je z hlediska druhého členem extrémně omezeného a zavřeného paradigmatu (formálně a většinou i sémanticky)“ (Čermák, 2007, s. 32), a zohledňuje tak aspekty syntagmatické i paradigmatické. (Díky tomuto př́stupu nejsou z oblasti frazeologie vyloučeny jednotky jednoslovné či syntagmata s monokolokabilní komponentou, jak je tomu při užití jiných definic. ${ }^{20} \mathrm{~V}$ SČFI jednoslovné jednotky kodifikované nejsou.) Klasifikace frazémů pak vychází ze strukturních hledisek, tj. př́islušnosti komponent frazému do stejné roviny, přičemž výsledný frazém pak náleží do roviny vyšší než komponenty (srov. ibid., s. 42 - 43). To se do jisté míry odráží i ve výstavbě slovníku. Slovníky začínají na jazykové rovině kolokací (SČFI 1 - 3), SČFI 4 zahrnuje různé typy frazémů propozičních a polypropozičních.

Význam slovníku uživatel docení nikoli při jeho zběžném prohlížení, ale až při řešení konkrétních problémů, resp. v konfrontaci s jinými lexikografickými produkty. To je př́pad

${ }^{16}$ Většina př́kladů je autorských, u SČFI 4 již byly využity i autentické př́klady z korpusu. Př́íklady význam frazému ilustrují povětšinou dobře, často i díky dialogické formě. Exemplifikace spolu s pečlivým popisem významu a kontextu užití i nabídkou synonym a antonym přispívá ke komplexnímu uchopení sémantické stránky frazému. Právě to bývá bolavým místem většiny slovníků.

${ }^{17}$ Mezijazyková ekvivalence je ve slovníku v samostatné kapitole krátce tematizována. SČFI formálně rozlišuje ekvivalenty strukturně shodné a neshodné. I přes to a přes nabídku cizojazyčných ekvivalentů nelze o SČFI mluvit jako o slovníku překladovém (takto viz např. Jarošová, 2011), už proto ne, že cizojazyčné frazémy jsou uváděny jen $\mathrm{k}$,velkým a plně zpracovaným heslům“. Překlad je pouze jeho sekundární funkcí, kterou nabízí jako bonus navíc. Zpracování překladových ekvivalentů v SČFI by si zasloužilo samostatný publikační výstup (k internacionalizmům v SČFI viz Mokienko, 2014). Lze ovšem konstatovat, že např́klad německojazyčné ekvivalenty jsou voleny ne vždy optimálně, srov. např. SČFI 3, s. 392: K (moct) si o(b)liznout všech deset/pět (prstů) je uveden jako ekvivalent frazém sich die Finger lecken (alle zehn Finger), kde se ale jedná spíš o význam frazému mít na něco zálusk.

${ }^{18}$ Tento fakt je (nejen např. $z$ hlediska nerodilých mluvčích češtiny) nutné výslovně ocenit. K intonaci tzv. pragmatických frazémů u (ne)rodilých mluvčích na př́kladě němčiny srov. Mackus (2011) a Lipinski (2011). Pro elektronickou verzi slovníku by se nabízely i nahrávky, jejichž absenci ale slovník vynahrazuje podrobným přehledem jednotlivých intonačních typů (srov. SČFI 4, s. 15nn.).

${ }^{19}$ Slovník užívá pojmů frazém a idiom. Čermák (2007, s. 33) zdůrazňuje, že s ohledem na rozdílné hledisko př́stupu $\mathrm{k}$ dané jednotce (formální rysy vs. význam) je smysluplné zachovat i dvojí označení. Kriticky k tomu např. Šichová (2013, s. 35 - 36).

${ }^{20}$ Srov. např. Burger (2003, s. 32). Problém tohoto př́stupu je zvláště např. v němčině zjevný u kompozit a jejich měnícího se pravopisu (zvlášt' vs. dohromady, tj. jedno vs. dvě, řidčeji více slov). Jako jeden z mála frazeologů z germanistických kruhů poukázal Hans Schemann v souvislosti s definicí frazému na fakt, že - jak ř́ká František Čermák - ,pravopis je špatný rádce“ (srov. Schemann 2011, s. 22). 
i sémantického oddílu hesel, jehož propracovanost patří k jedné z největších předností SČFI. Připomeňme, že slovník nabízí nejen popis vlastního významu syntagmatu včetně pragmatické složky, ale též podrobný popis kontextu (a situace), tj. uvádí obvyklé účastníky děje, jejich úlohy a vztahy mezi nimi, popis valence a kolokability, okolnosti místní a časové. Právě díky tomuto důmyslnému a ve všech dílech důsledně uplatňovanému systému popisu sémantiky frazému je SČFI jedinečný. ${ }^{21}$

SČFI za dobu své existence získal status výjimečnosti, ${ }^{22}$ a to především díky detailnosti, kterou se frazeologické slovníky jiných jazyků, a to ani těch mnohem větších než čeština, pochlubit nemohou. ${ }^{23}$ Aureola „mistrovského díla české a světové frazeologie“ (Jarošová 2011, přel. K.Š. - M.Š.), která ho doprovází, je zasloužená a nic na tom nemění ani to, že některé aspekty zpracování mohou být předmětem diskuze. Jeho mnohá pozitiva v kontextu dnešní doby významněji relativizuje pouze chybějící elektronická verze. ${ }^{24}$ Skutečnost, že nyní vychází SČFI 5 (Onomaziologický slovník), jež se od předchozích čtyř svazků liší postupem od významu k formě, a nabízí tak svým uživatelům méně běžný typ frazeologického slovníku, je proto mimořádná událost.

Doprovodné texty jsou v SČFI 5 oproti předchozím dílům velmi stručné, sestávají z pěti kapitol, vysvětlivek a bibliografie na celkových zhruba deseti stranách. ${ }^{25}$ Kapitoly 1 (Onomaziologické slovniky) a 3 (Český onomaziologický slovník OSČFI, jeho principy a struktura) krátce charakterizují onomaziologické slovníky jako typ lexikografického výstupu, princip sjednocování frazémů do hesel podle významu, znaky užitého metajazyka apod. Právě tyto kapitoly by si ovšem zasloužily podrobnější zpracování již s ohledem na to, že tento typ zpracování ve frazeografii není obvyklý ${ }^{26}$ a že se text dotýká několika zajímavých, pro českou frazeologii málo probádaných a přitom mnohdy diskutabilních témat (např. frazeologická synonymie a antonymie, metajazyk, utváření skeletonových definic). Ostatní kapitoly (kap. 2 Frazeologie a idiomatika jako oblast a celek, kap. 4 Heslo onomaziologického slovníku ukázka, kap. 5 SČFI jako celek - slovník abecední a onomaziologický a jejich poměr v přehle$d u$ ) rámují tento díl do širšího kontextu celého slovníku a představují př́íklady konkrétních hesel. I tyto texty by mohly být obsažnější. Je ovšem pravděpodobné, že se autor s odkazem

${ }^{21} \mathrm{~K}$ tomu na př́ikladu otázek rodových restrikcí frazémů a ve srovnání s němčinou viz např. Šichová (2017).

${ }^{22}$ Srov. např. Kučera (1995, s. 98), Jarošová (2011, s. 51), Mokienko (2014, s. 124).

${ }^{23}$ Srov. např. k německojazyčné frazeografii, finštině a švédštině Korhonen (2011), ve srovnání s frazeografií českou srov. Šichová - Šemelík (2016a), na příkladu přísloví ve slovnících srov. Mieder (1999).

${ }^{24}$ Nutnost listování ve slovníku je obecně vnímána negativně (srov. Engelberg - Lemnitzer, 2009, s. 86). Uživatelé napřr. z řad tzv. generace Y (narození cca v letech 1980 - 2000) jsou navyklí na rychlejší príistup k informacím (v tomto smyslu viz Barnes - Marateo - Ferris, 2007, s. 3), než který jim tištěný SČFI může nabídnout.

${ }^{25}$ SČFI 5 např. neobsahuje žádné bližší informace k profilu zamýšlených adresátů, údaje typu „,pro vytř́ibeného autora, autora učebnic a slovníků, překladatele, studenta, ale i lingvistu“ na zadním přebalu slovníku jsou - jak tomu bývá - spíše reklamního rázu. Též údaje ke konkrétním slovníkovým funkcím, které SČFI 5 má plnit, chybí. Katalog kritérií k takovému popisu viz Tarp (1995).

${ }^{26}$ Srov. ale např. ruský onomaziologický frazeologický slovník novějšího data Baranov - Dobrovol’skij (2007). Zvláštním typem onomaziologického slovníku je slovník synonym. Zde můžeme v oblasti frazeografie odkázat např. na Schemanna (2012). 
na př́slušné ostatní díly nechtěl opakovat a uživatel najde podrobné informace v dílech $1-4$ (odkazy jsou v kap. Bibliografie). Ke kap. Bibliografie na s. 16 poznamenejme, že jako bibliografie k české frazeologii a frazeologii jako také neposlouží (což je škoda), na to je príiliš jednostranná, když obsahuje téměř jen texty Františka Čermáka z jednotlivých dílů SČFI. O př́ispěvky k problematice frazeografie a tezaurů obecně ovšem také nejde, protože pak by v ní chyběly např́iklad př́spěvky XVII. kapitoly ze svazku Burger et al. (2007) nebo tituly D. Dobrovol'ského (např. 1995) aj.

Slovník má makrostrukturu s abecedním řazením v tom smyslu, že abecedně řazená záhlaví tvoří metajazykové definice (,skeletonové definice“, s. 8), které zastřešují různé množství více či méně synonymních frazémů, srov. např.: „VĚTné on je tlustý • Roste mu břicho. • Břicho se mu nevejde do kalhot. • Dveře mu nestačí. • Je jako/to koule. • Jen kyne. n. Všechno na něm jen kyne. • Podlaha se pod ním třese. • Prázdnej/prázdný pytel nestojí. • Zarůstá sádlem. • Hřeje ho sádlo. • Sotva se valí. • Ten je širší než delší.“ (s. 290).

SČFI 5 obsahuje - i podle námi provedených výpočtů - cca 11 tisíc hesel $\left(11.166\right.$, s. 10). ${ }^{27}$

Každé heslo začíná označením obecné funkční platnosti jednotlivých frazémů (přirovnání, neslovesné, slovesné a větné výrazy), které zároveň udává, ve kterém z prvních čtyř svazků lze prř́slušný frazém nalézt, a výše zmíněnou skeletonovou definicí. Následují konkrétní frazémy. Součástí některých hesel jsou odkazy, opozita, resp. český ekvivalent u cizojazyčných frazémů. „Vše ostatní z významu a úzu uživatel však musí znát, aby si vybral vhodný výraz, anebo si informaci musí doplnit vyhledáním v abecedním slovníku, resp. v jednom ze čtyř abecedních slovníkư“ (s. 11). To je vzhledem k typu slovníku na jednu stranu pochopitelné, na druhou stranu by doplnění např. základního kontextu a/nebo stylistických kvalifikátorů, jakkoli je s nimi spojeno mnoho problémů (srov. Vachková, 2013, inter alia) uživatelský komfort zvýšilo. Bez těchto informací hrozí reálné nebezpečí, že např. nerodilý mluvčí češtiny text Internacionály (Již vzhưru, psanci této země, již vzhưru všichni, jež hlad zhnět...) v heslové stati pojd'me! (s. 327) interpretuje či použije chybně. Také z tohoto důvodu ne zcela sdílíme názor, že SČFI 5 ,lze užívat nezávisle na čtyřech předchozích svazcích“ (Vašků, 2017, s. 140).

Alfou a omegou onomaziologického slovníku je zařazení heslářových položek do významových tříd. Skeletonovou definici lze chápat jako kondenzát významu, pod nějž spadají jednotlivé frazémy s jejich významy. Sjednocením těchto významů do jediné třídy nutně dochází k určitému zjednodušení, nebot' skeletonová definice je schopna vystihnout jen společné „obrysové sémantické jádro“ (s. 7n.) seskupených frazémů. Oceňujeme přitom otevřenost, se kterou autoři tyto problémy a s nimi související omezení tematizují (ibid.). Podobná reflexe nebývá v lexikografii pravidlem. Následující přehled, jenž není úplný, zkreslení tohoto typu ilustruje. Při vědomí toho, jak komplikované vystižení významu je, tyto řádky nechápeme nutně jako kritiku: (a) Zda uživatel bude frazémy typu Strč prst skrz krk. hledat zrovna pod já hraju si (s. 152), je sporné. Definice jazykolam by možná byla uživatelsky př́hodnější. (b) Sémantika př́sloví Mưj dům (je) můj hrad. je komplikovaná v češtině i v jiných jazycích, ${ }^{28}$

${ }^{27}$ Výpočty byly provedeny podle Engelberg - Lemnitzer (2009, s. 193n.). Náhodně byla vybrána cca $2 \%$ stránek hesláře. Na těchto stránkách bylo spočítáno množství uvedených frazémů, jejich množství v celém slovníku bylo vypočítáno na základě přímé úměry.

${ }^{28} \mathrm{~K}$ tomuto přísloví $\mathrm{v}$ němčině a kontrastivnímu německo-českému pohledu srov. Šichová Šemelík (2016b, s. 95n.). 
jejím dominantním rysem ale není, že někdo upřednostňuje samotu (já chci být sám, s. 153), nýbrž že si člověk doma může dělat, co chce, resp. že člověk si svůj domov může zařídit podle svého. (c) Frazém Za našich mladejch let bejval svět jako květ. by se vzhledem k určitému nádechu melancholie, nostalgie či stesku spíš než pod život je krásný (s. 526) lépe hodil pod život je těžký ted' (ibid.) nebo život byl krásný dříve.

Protože důvody jeho užití nemusejí být uživatelům zřejmé, zasloužil by si specifický slovosled skeletonových definic komentář v doprovodných textech. Formulace jako např. já hodnotím to velmi (s. 152), mít pojetí něčeho dobré (s. 209) aj. působí dosti anti-intuitivně.

Stejně tak se nabízí otázka výběru vhodné slovesné formy pro heslo. V některých př́ípadech najdeme první osobu singuláru nebo první osobu plurálu včetně osobních zájmen, jindy imperativy, v dalších zase infinitiv. To je pro uživatele matoucí. Dá se předpokládat, že - nebot' mu není nabídnuto vysvětlení či konkrétní postup - patrně bude intuitivně nejprve hledat pod začátečním písmenem slovesa, nikoli (pro češtinu fakultativního) osobního zájmena. $\mathrm{V}$ tom př́padě může řazení hesla my můžeme předpokládat pod $m y$, nikoli např́íklad pod předpokládat, předpokládejme, předpoklad nebo já blahopřeju pod já, nikoli pod (blaho) přát či (blaho)přání působit uživatelům potíže, než si na tento př́stup a jeho vnitřní logiku zvyknou. $^{29}$

Z různých dalších drobností zde upozorněme jen na tyto: (a) Každý slovník zastarává, resp. neubrání se kodifikování jednotek v úzu již méně frekventovaných. Např. frazém Přeskoč, přelez, jenom nepodlez. (s. 24) je dle internetových dokladů (Google.cz, 1. 9. 2017) okrajový. Častější je neuvedené Přeskoč, přelez, ale nepodlez. (7 vs. 1490 dokladů). (b) Překlad Whisky on beer makes onelyou queer. jako Whisky po pivu tě dělá divným. (s. 494) je velmi kostrbatý. Poznámka v doprovodných textech, že se mnohdy jedná o doslovný překlad, nikoli funkční ekvivalent, by byla na místě.

SČFI 5 je zatím posledním svazkem lexikografického díla, o jehož vysokých kvalitách dnes pochybuje málokdo. Konstatování, že uživatel „má nyní možnost na 528 stranách jediného svazku OSČFI najít vše, co kdy chtěl vědět o české frazeologii“" (Vašků 2017, s. 142) je sice nadnesené, autorům pátého slovníku se ale sluší $\mathrm{k}$ jejich novému dílu pogratulovat. Řadu SČFI doplňuje důstojně.

Co říci závěrem? Kdyby nás někdo požádal o frazeologickou charakteristiku SČFI 1 - 5, odpověděli bychom To nemá chybu! SČFI samozřjmě zcela dokonalý není, jinak to ale ani nejde. Chyby budou, dokud budou slovníky. Na několik problematických aspektů, které by mohly být pro eventuální další vydání zrevidovány (šikovné spolupracovníky jakož i dostatek finančních prostředků editorům ze srdce přejeme!), jsme zde upozornili. Celková koncepce lingvistická a lexikografická učinila ze SČFI již před desetiletími vlajkovou lod' světové frazeografie. Nelze než autorům i uživatelům přát, aby jeho žádaná (a nakladatelstvím avizovaná) elektronická podoba vyšla, a aby to bylo co nejdříve.

\section{Literatura}

BARANOV, Anatolij Nikolaevič - DOBROVOLSKIJ, Dmitrij: Slovar'-tezaurus sovremennoj russkoj idiomatiki. Moskva: Mir enciklopedii Avanta 2007.

\footnotetext{
${ }^{29} \mathrm{~K}$ tomu kriticky též Vašků (2017, s. 142).
} 
BARNES, Kassandra - MARAETO, Raymond C. - FERRIS, Pixy S.: Teaching and Learning with the Net Generation. In: Innovate: Journal of Online Education, 2007, roč. 3, č. 4. Dostupné na: http://nsuworks.nova.edu/cgi/viewcontent.cgi?article=1091\&context=innovate (1. 9. 2017).

BURGER, Harald - DOBROVOLSKIJ, Dmitrij - KÜHN, Peter -NORRICK, Neal R. (eds.): Phraseologie. Ein internationales Handbuch der zeitgenössischen Forschung. Berlin - New York: Walter de Gruyter 2007.

ČERMÁK, František: Frazeologie a idiomatika česká a obecná. Czech and General Phraseology. Praha: Karolinum 2007.

ČERMÁK, František - FILIPEC, Josef: Česká lexikologie. Praha: Academia 2007.

ČERMÁK, František - BLATNÁ, Renata (eds.): Manuál lexikografie. Jinočany: H\&H 1995.

DOBROVOL'SKIJ, Dmitrij: Kognitive Aspekte der Idiom-Semantik. Studien zum Thesaurus deutscher Idiome. Tübingen: Gunter Narr 1995.

ENGELBERG, Stefan - LEMNITZER, Lothar: Lexikographie und Wörterbuchbenutzung. 4. Aufl., Tübingen: Stauffenburg 2009.

HENSCHEL, Helgunde: Die Phraseologie der tschechischen Sprache. Frankfurt am Main: Peter Lang 1993.

JAROŠOVÁ, Alexandra: Majstrovské dielo českej a svetovej frazeológie (František Čermák a kol.: Slovník české frazeologie a idiomatiky). In: Jazykovedný časopis, 2011, roč. 62, č. 1, s. 51 - 64 . Dostupné na: http://www.juls.savba.sk/ediela/jc/2011/1/jc2011_01.pdf (1. 9. 2017).

KORHONEN, Jarmo: Phraseologie und Lexikografie. Phraseologismen in ein- und zweisprachigen Wörterbüchern mit Deutsch. Burlington/Vermont: The University of Vermont 2011.

KUČERA, Karel: Recenze Slovník české frazeologie a idiomatiky. In: Naše řeč 1995, č. 2/78, s. 96 - 99. Dostupné na: http://nase-rec.ujc.cas.cz/archiv.php?lang=en\&art=7236 (1. 9. 2017).

LIPINSKI, Silke: Zu Routineformeln im einsprachigen deutschen Lernerwörterbuch. Eine Untersuchung anhand von zwei Lernerwörterbüchern. In: Beiträge zur pragmatischen Phraseologie. Eds I. Hyvärinen - A. Liimatainen. Frankfurt am Main: Peter Lang 2011, s. 83 - 91.

MACKUS, Nicole: Die Akzentuierung von Routineformeln. Eine Untersuchung anhand von Hörmustern In: Beiträge zur pragmatischen Phraseologie. Eds I. Hyvärinen - A. Liimatainen. Frankfurt am Main: Peter Lang 2011, s. $45-56$.

MIEDER, Wolfgang: Sprichwörter in den größeren allgemeinen und phraseologischen Wörterbüchern. In: Studien zur zweisprachigen Lexikographie mit Deutsch. Eds H. E. Wiegand. Germanistische Linguistik, 1999, s. 1 - 40.

MIEDER, Wolfgang: International Bibliography of Paremiology and Phraseology, Volume $1 \& 2$. Berlin - New York: Walter de Gruyter 2009.

MOKIENKO, Valerij M.: Evropskie jazykovye paralleli v „Slovníku české frazeologie a idiomatiky.“ In: Radost z jazyků. Sborník př́spěvků k 75. narozeninám prof. Františka Čermáka. Eds V. Petkevič - A. Adamovičová - V. Cvrček. Praha: Nakladatelství Lidové noviny - Ústav českého národního korpusu 2014, s. $124-137$.

MUKAŘOVSKÝ, Jan: Př́íloví jako součást kontextu. In: Cestami poetiky a estetiky. Praha 1971, s. $277-359$.

PERKUHN, Rainer - BELICA, Cyril: Korpuslinguistik - Das unbekannte Wesen oder Mythen über Korpora und Korpuslinguistik. In: Sprachreport, 2006, roč. 22, č. 1, s. 2 - 8. Dostupné na: http:// pub.ids-mannheim.de/laufend/sprachreport/pdf/sr06-1a.pdf (1.9. 2017).

PETRÁČKOVÁ, Věra: Nad Slovníkem české frazeologie a idiomatiky. In: Naše řeč, 1985, roč. 68, č. 5, s. 249 - 253. Dostupné na: http://nase-rec.ujc.cas.cz/archiv.php?art=6582 (1. 9. 2017).

SCHEMANN, Hans: Deutsche Idiomatik. Wörterbuch der deutschen Redewendungen im Kontext. Berlin - New York: Walter de Gruyter 2011.

SCHEMANN, Hans: Synonymwörterbuch der deutschen Redensarten. Berlin - New York: Walter de Gruyter 2012. 
SCHINDLER, Franz: Das Sprichwort im heutigen Tschechischen. Empirische Untersuchung und semantische Beschreibung. München: Sagner 1993.

ŠEMELÍK, Martin: Recenze „Deutsch-tschechisches Wörterbuch der Phraseologismen“. In: International Journal of Lexicography, 2010, roč. 23, č. 4, s. 486 - 491. Dostupné na: http://ijl.oxfordjournals. org $/$ content $/ 23 / 4 / 486$.full?keytype $=$ ref\&ijkey $=$ WSe3LV4kSnJU4H1 (1. 9. 2017).

ŠICHOVÁ, Kateřina: Recenze „Deutsch-tschechisches Wörterbuch der Phraseologismen“. In: Časopis pro moderní filologii, 2011, roč. 93, č. 2, s. 126 - 130.

ŠICHOVÁ, Kateřina: „Mit Händen und Füßen reden.“ Verbale Phraseme im deutsch-tschechischen Vergleich. Tübingen: Stauffenburg - Julius Groos Verlag 2013.

ŠICHOVÁ, Kateřina: „Tak dlouho na ni dělal oči, až ho požádala o ruku?“ K rodovým restrikcím a preferencím frazémů v češtině. In: Svět v obrazech a ve frazeologii I. Eds L. Janovec - R. Kvapilová-Brabcová - V. Skibina - Z. Wildová. Praha: PedF UK 2017, s. 457 - 476.

ŠICHOVÁ, Kateřina - ŠEMELÍK, Martin: Několik poznámek k současné německo-jazyčné frazeografii. In: Časopis pro moderní filologii 2016a, roč. 98, č. 2, s. 241 - 253. Dostupné na: http://sites. ff.cuni.cz/casopispromodernifilologii/wp-content/uploads/sites/9/2016/09/katerina_sichova_241-253-1. $\operatorname{pdf}(1.9 .2017)$.

ŠICHOVÁ, Kateřina - ŠEMELÍK, Martin: „Was nicht ist, kann noch werden.“Zur Parömiodidaktik im Tschechisch-als-Fremdsprache-Unterricht 2. In: Beiträge zur Fremdsprachenvermittlung, 2016b, č. 57, s. 61 - 104. Dostupné na: http://www.vep-landau.de/fileadmin/user_upload/bzf/Hefte/ bzf_2016_57.pdf (1.9.2017).

TARP, Sven: Wörterbuchfunktionen: Utopische und realistische Vorschläge für die bilinguale Lexikographie. In: Studien zur bilingualen Lexikographie mit Deutsch II. Ed. H. E. Wiegand, Hindesheim - New York 1995, s. 17 - 62.

VACHKOVÁ, Marie: K historii a současné praxi stylistických markerů v německé lexikografii a vznikající Německo-české lexikální databázi. Jazykovědné aktuality, 2013, roč. 50, č. 3-4, s. 117 124. Dostupné na: http://jazykovednesdruzeni.cz/JA_2013_3_4.pdf (1.9. 2017).

VAŠKU゚, Kateřina: Recenze Čermák, František - Holub, Jan (2016): Slovník české frazeologie a idiomatiky. Sv. 5 - Onomaziologický slovník, Leda, Praha; Časopis pro moderní filologii, 2017, roč. 99, č. 1, s. 140 - 143. Dostupné na: https://sites.ff.cuni.cz/casopispromodernifilologii/wp-content/uploads/sites/9/2017/06/Kate\%C5\%99ina_Va\%C5\%A1k\%C5\%AF_140-143.pdf (1. 9. 2017).

Katerina Šichová

Bohemicum Regensburg-Passau, Universität Regensburg, Německo

Martin Šemelik

Ústav germánských studií, Filozofická fakulta Univerzity Karlovy, Česká republika 